
\title{
Effect of Use of Duckweed Powder as a Fish Feed on Polyculture of Carps
}

\author{
M. Paul, A. C. Barman, M. F. Siddque ${ }^{2}$, A. Bhadra ${ }^{2}$ and M. S. Rahman ${ }^{1}$
}

BFRI, Freshwater station, Mymensingh, ${ }^{1}$ Department of Fisheries Management, BAU, Mymensingh;

${ }^{2}$ BFRI, Headquaters, Mymensingh

\begin{abstract}
An experiment on the use of duckweed (Lemna minor) powder as an ingredient of feed on production of rui (Labeo rohita), mrigal (Cirrhinus cirrhosus) and silver carp (Hypophthalmicthys molitrix) in polyculture, was conducted in six ponds for a period of three months. The experiment was carried out under two treatments, each with three replications. Mean survival rates under treatment-I and treatment-II were $95.55 \%$ and $88.88 \%$ respectively. The specific growth rate (SGR, \% per day) of the fish found under treatment-I and treatment-II were $0.28 \%$ and $0.25 \%$ respectively. The calculated net fish production of the ponds under treatment-I was 1.416 ton/ha/yr and that of the ponds under treatment-II (control) was 0.846 ton/ha/yr. The net fish production of T-I was significantly $(\mathrm{p}<5 \%)$ higher than that of T-II.
\end{abstract}

Key words: Fingerlings, Mrigal, Rui, Silvercarp, SGR\%

\section{Introduction}

Duckweeds, small floating aquatic plants belonging to the family Lemnaceae are widely available in Bangladesh. This family consists of 4 genera viz., Lemna, Spirodela, Wolffia, Wolffiella of which about 40 species have so far been identified. Lemna minor, L. minima, L. gibba and L. perpusilla are some important species of the genera Lemna. Duckweed has been shown to be readily consumed by a variety of herbivorous fish such as grass carp (Ctenopharyngodon idella), tilapia (Oreochromis niloticus) and rajpunti (Puntius gonionotus). It may be fed either in the form of fresh or dried powder as in combination of other feed components such as wheat bran, rice bran etc. Duckweed protein has higher concentration of the essential amino acid, Lysine and methionine, than most plant proteins and more closely resembles animal protein in that respect (Journey et al., 1991). Considering all these factors, duckweed powder has been selected as an ingredient of feed for the present experiment of polyculture of mrigal, rui and silver carp. Few studies on the production and use of duckweed as feed for fishes in mono and polyculture but a very few research works have been done on duckweed powder-based aquaculture in Bangladesh. There are some important research works, on effects of fish population density on growth and production of fishes were done by
Alim et al. (2005); Hepher et al. (1989); Lakshmanan et al. (1968); Orpwood et al. (2004); Coman et al. (2007); Lorenzen (2001); Saillant et al. (2003) in overall cases of fisheries development. Considering the great potentialities of the use of duckweed powder in aquaculture the present research work was to evaluate the use of duckweed powder as an ingredient of low cost supplementary feed on the survival and growth of Mrigal, Rui and Silver carp in polyculture; to compare the growth and production of Mrigal, Rui and Silver carp in polyculture; and to compare cost and benefit of Mrigal, Rui and Silver carp productions between two different treatments.

\section{Materials and Methods}

\section{The ponds under the study}

The ponds were rectangular in size and similar in area (about $40 \mathrm{~m}^{2}$ ), depth and basin bottom soil type and contour. The experiment was conducted in a series of six earthen ponds each having an average depth of $0.74 \mathrm{~m}$.

\section{Experimental design}

The experiment was performed in Completely Randomized Design (CRD) in which two treatments (T-I and T-II) each with three replications were used (Table 1).

Table 1. The layout of the experiment

\begin{tabular}{|l|l|c|l|l|}
\hline Treatment & Pond no. & Replication & Stocking of fingerlings & Description \\
\hline $\begin{array}{l}\text { T-I (Feeding with duckweed } \\
\text { powder and rice bran in ratio } \\
\text { of 3:1) }\end{array}$ & $\mathrm{P}_{1}, \mathrm{P}_{2}$ and $\mathrm{P}_{5}$ & 3 & $\begin{array}{l}60 \text { in each pond of } 1 \\
\text { decimal }\end{array}$ & $\begin{array}{l}\text { Polyculture of } \text {. } \text { mrigala, } \\
\text { L. rohita } \text { and } \text { H. molitrix }\end{array}$ \\
\hline T-II (without feed) & $\mathrm{P}_{3}, \mathrm{P}_{4}$ and $\mathrm{P}_{6}$ & 3 & $\begin{array}{l}60 \text { in each pond of } 1 \\
\text { decimal }\end{array}$ & $\begin{array}{l}\text { Polyculture of } \text { C. mrigala, } \\
\text { L. rohita } \text { and } \text { H. molitrix }\end{array}$ \\
\hline
\end{tabular}




\section{Pond preparation}

Seven days after liming urea and triple super phosphate (TSP) were applied at the rate of $100 \mathrm{~g} /$ decimal and 100 $\mathrm{g} /$ decimal respectively as initial doses.

\section{Stocking of fish}

Fingerlings of $L$. rohita, $C$. mrigala and $H$. molitrix were stocked in the ponds at the density of 60 fish per decimal after 7 days of fertilization. The initial average length of $L$. rohita, $C$. mrigala and $H$. molitrix were $11.96 \mathrm{~cm}, 9.33 \mathrm{~cm}$ and $9.13 \mathrm{~cm}$ respectively. The initial average weight of $L$. rohita, C. mrigala and H. molitrix were $22.67 \mathrm{~g}, 8.33 \mathrm{~g}$ and 6.83 g respectively.

\section{Supply of feed}

At first sun dried duckweed was made powder. The weight of duckweed powder and rice bran was taken and packaged in polythene bags at the ratio of $3: 1$ and then supplied to the ponds of treatment-I (pond nos. $\mathrm{P}_{1}, \mathrm{P}_{2}$ and $\mathrm{P}_{5}$ ) at the rate of $4 \%$ of the total body weight of the fishes everyday.

\section{Harvesting of fish}

At the end of the experiment the water of the ponds were pumped out and all the fishes were harvested. Then the final growth gained by the fishes was recorded by measuring the length $(\mathrm{cm})$ and weight $(\mathrm{g})$ of the recorded fishes by using a measuring scale and a balance respectively.

\section{Estimation of survival rate, growth and production of fish}

(i) The survival rate was estimated by the following formula:

$$
\text { Survival rate }(\%)=\frac{\text { No. of harvested fishes }}{\text { Initial no. of fishes }} \times 100
$$

(ii) Specific growth rate (SGR \% per day) was estimated by the following formula:

$$
\text { SGR (\% per day) }=\frac{\log _{\mathrm{e}} \mathbf{W}_{2}-\mathbf{L o g}_{\mathrm{e}} \mathbf{W}_{1}}{\mathbf{T}_{2}-\mathbf{T}_{1}} \times \mathbf{1 0 O} \text { (after Brown, 1957) }
$$

Where

$\mathrm{W}_{1}=$ Initial live body weight $(\mathrm{g})$ at time $\mathrm{T}_{1}$ (day)

$\mathrm{W}_{2}=$ Final live body weight $(\mathrm{g})$ at time $\mathrm{T}_{2}$ (day)

(iii) Calculated Gross Production (ton/ha/yr)

$$
=\frac{\text { Gross weight }(\mathrm{kg}) \text { of fish per decimal per month } \times 250 \times 12}{1000}
$$

(iv) Calculated Net Production (ton/ha/yr)

$$
=\frac{\text { Net weight }(\mathrm{kg}) \text { of fish per decimal per month } \times 250 \times 12}{1000}
$$

\section{Statistical analysis}

T-test of net fish productions of the ponds under treatment-I and treatment-II was done by a computer using SPSS (Statistical Packages for Social Science) package programme.

\section{Results and Discussion}

\section{Survival rate, growth and production of fish}

The survival rate (\%) of fishes was slightly different in different treatments. The survival rate in treatment-I was $95.55 \%$ and in treatment II was $88.88 \%$. The specific growth rates (SGR\% per day) of fishes in different treatments were different. The production of fishes was different in different treatments. The gross and net productions of fish of the ponds under treatment-I and treatment-II have been presented in the Figs. 1 and 2.

\section{Cost-return relationship}

Cost and return were determined on the basis of production. Only the cash costs consisted of those costs which had to pay out of a related project fund to acquire the relevant inputs have been considered by excluding those costs like land use and interest on operating the capital. Net returns were calculated on the basis of the current market price of selling the total amount of fishes harvested from the ponds of both treatments (Fig. 3) 

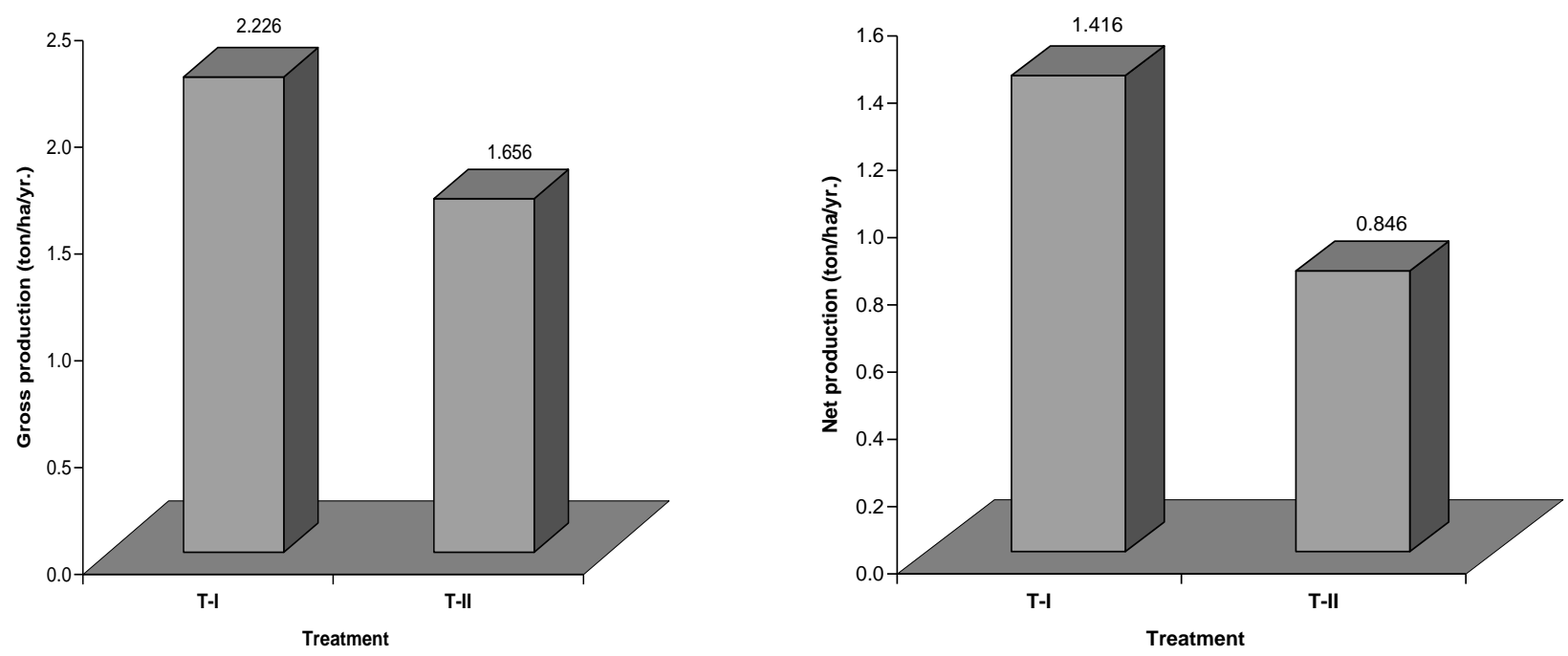

Fig. 1 and 2. Gross and net productions of the fishes under treatments-I and II

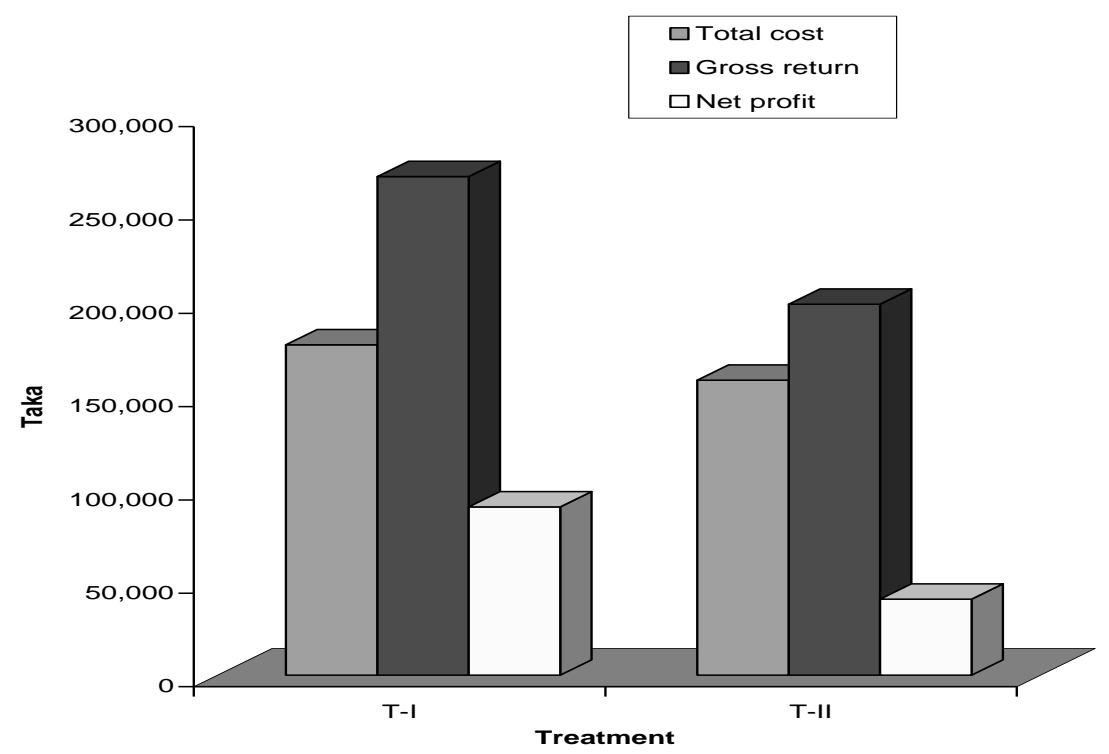

Fig. 3. Total cost, gross return and net profit per hectare per year in Taka under treatments I and II

\section{Discussion}

In the present experiment, the survival rates were different in different experimental ponds as well as the mean survival rates were higher $95.55 \%$ and $88.88 \%$ for treatment-I and treatment-II, respectively which result are agreed to the findings of Haque (2005). They recorded that the survival rates of $89.50 \%$ and $90 \%$ under treatment-I and treatment-II respectively in the monoculture of Thai sharpunti Puntius gonionotus. Kohinoor et al. (1993) obtained a survival rate of 86 to $94 \%$ in the monoculture of Thai sharpunti. The specific growth rates of rui, mrigal and silver carp (SGR\% per day) under treatment-I and treatment-II varied from 0.28 to $0.25 \%$. Similarly, Hossain et al. (1997) reported that the rate of $5 \%$ of total body weight daily whereas Khatun (2004) fed fresh duckweed at the rate of $40 \%$ of the total body weight. Net production of fish of treatment-I increased than that of treatment-II and it was $167.38 \%$ in comparison to treatment-II where net production was taken for $100 \%$. Kabir (2003) found 7.77 ton/ha/yr gross production in duckweed-based polyculture system. Cost-benefit or percent benefit on investment under treatment-I and treatment-II were $51 \%$ and $26 \%$ respectively. 


\section{Conclusion}

According to the findings of the present experiment, it may be concluded that due to the availability and cost-effectiveness of duckweed powder it has significant effect as feed ingredient considering the economic aspect for polyculture. By adopting this method, production cost of fish culture can be reduced considerably. So, duckweed powder-based polyculture technology may be recommended for the resource-poor rural fish farmers of the country because this technology can be an economically highly viable and sustainable technology for improving their livelihood.

\section{References}

Alim, M. A. 2005. Developing a polyculture technique for farmers consumption and cash crop. Ph.D. Dissertation, Deptt. of Fisheries Management, Bangladesh Agricultural University, Mymensingh. p. 192.

BBS (Bangladesh Bureau of Statistics). 2004. Monthly Statistical Bulletin of Bangladesh. September 2004. Bangladesh Bur. Stat., Stat. Div., Ministry of Planning, Govt. of The People's Republic of Bangladesh.

Coman, G. J.; Arnold, S. J.; Jones, M. J. and Preston, N. P. 2007. Effect of rearing density on growth, survival and reproductive performance of domesticated Penaeus monodon Aquacult., 264(1/4): 175-183.

DoF. 2009. National Fish Week, 30 July to 5 August, 2009. Fish Culture in Flood affected Land. Dept. of Fisheries, Ramna, Dhaka.

Haque, M.S. 2005. Use of duckweed (Lemna minor) as supplementary feed in monoculture of Sharpunti (Puntius gonionotus). MS thesis, Deptt. of Fisheries Management, Bangladesh Agricultural University, Mymensingh. 87 pp.

Hepher, B.; Milstein, A.; Leventer, H. and Teltsch, B. 1989. The effect of fish density and species combination on growth and utilization of natural food in ponds. Aquacult. Fish. Managt., 20: 59-71.

Hossain, M.A., M. Ahmed and M. N. Islam. 1997. Mixed culture of fishes in seasonal ponds through fertilization and feeding. Bangladesh J. Fish. Res., 1(2): 9-18.

Journey, T.; Skillicorn, P. and Spira, B. 1993. Ducked Auaculture, A new farming system for developing countries. Emena Technical Deptt., Agric. Div., The World bank. p. 76.

Kabir, A. N. M. A. 2003. Use of duckweed (Lemna minor) as feed for fishes in polyculture. M.S. thesis, Deptt. of Fisheries Management, Bangladesh Agril. University, Mymensingh.

Khatun, B. 2004. Effects of duckweed (Lemna minor) as supplementary feed on monoculture of tilapia (Oreochromis niloticus). M.S. thesis, Deptt. of Fisheries Management, Bangladesh Agricultural University, Mymensingh.

Khondker, M. and S. Rahim. 1993. Investigation on the water quality of Dhanmondi lake, Bangladesh. Periphytic and planktonic algae as indicators. Bangladesh J. Botany, 2(1):49-53.

Lakshmanan, M. A. V.; Sen, P. R.; Murty, D. S. and Chakraborty, D. P. 1968. Preliminary study on the rearing of carp finerlings. Indian J. Fish., 15(1\&2): 40-52.

Lorenzen, K. 2001. Using population models to assess culture-based fisheries: a brief review with an application to the analysis of stocking experiments. Reservior and culture based fisheries: biology and management. Proceedings of an International Workshop held in Bangkok, Thailand, from 15-18 February, 2000. pp. 257-265.

Opuszynski, K. 1979. Silver carp, Hypophthalmichthys molitrix (Val.), in carp ponds. III. Influence on ecosystem. Ekologie Polski., 27: 117-133.

Orpwood, J. E.; Griffiths, S. W. and Armstrong, J. D. 2004. Effect of density on competition between wild and hatchery reared Atlantic salmon for shelter in water. J. Fish Biol., 65(1): 201-209.

Saillant, E. ; Fostier, A. ; Haffray, P. ; Menu, B. ; Laureau, S. ; Thimonier, J. and Chatain, B. 2003. Effects of rearing density, size grading and parental factors on sex ratios of the Sea bass (Dicentrarchus labrax L.) in intensive aquaculture. Aquacult., 221(1/4): 183-206. 